Review

\title{
Meat nutritional composition and nutritive role in the human diet
}

\author{
Paula Manuela de Castro Cardoso Pereira * , Ana Filipa dos Reis Baltazar Vicente ${ }^{1}$ \\ CiiEm - Centro de Investigação Interdisciplinar Egas Moniz, Egas Moniz, Cooperativa de Ensino Superior, C.R.L., Quinta da Granja, Monte de Caparica, 2829-511 Caparica, Portugal
}

\section{A R T I C L E I N F O}

\section{Article history:}

Received 17 April 2012

Received in revised form 15 September 2012

Accepted 18 September 2012

Available online 31 October 2012

\section{Keywords:}

Meat

Nutritional composition

Protein

Iron

B12

Saturated fat

\begin{abstract}
A B S T R A C T
Meat has exerted a crucial role in human evolution and is an important component of a healthy and well balanced diet due to its nutritional richness. The present review attempts to sum up meats role and importance in human nutrition as well as examine some pejorative beliefs about meat consumption.

Meat is a valuable source of high biological value protein, iron, vitamin B12 as well as other B complex vitamins, zinc, selenium and phosphorus. Fat content and fatty acid profile, a constant matter of concern when referring to meat consumption, is highly dependent on species, feeding system as well as the cut used. Pork meat can have the highest fat content but poultry skin is not far behind. It is also crucial to distinguish meat cuts from other meat products especially regarding its association with disease risk.

As in other dietary components, moderation is advisable but meat has been shown to be an important component of a balanced diet.
\end{abstract}

(c) 2012 Elsevier Ltd. All rights reserved.

\section{Contents}

1. Introduction . . . . . . . . . . . . . . . . . . . . . . . . . . . . . . . . . . . . . 586

2. The role of meat in human evolution. . . . . . . . . . . . . . . . . . . . . . . . . . . . . . . . . . . . . . . 586

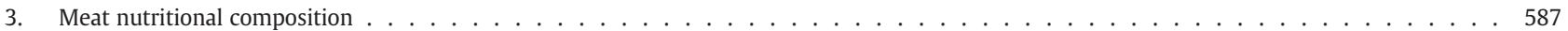

3.1. Meat protein content and protein value . . . . . . . . . . . . . . . . . . . . . . . . . . . . . . . . . . . . 587

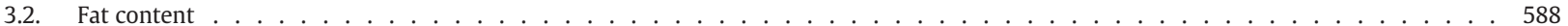

3.2.1. Fatty acid composition. . . . . . . . . . . . . . . . . . . . . . . . . . . . . . . . 588

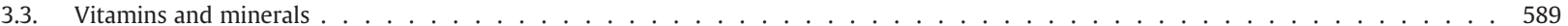

3.3.1. Meat, a valuable iron source . . . . . . . . . . . . . . . . . . . . . . . . . . . . . . . . . 589

3.3.2. Vitamin B12 in meat. . . . . . . . . . . . . . . . . . . . . . . . . . . . . . . 590

3.3.3. Other vitamins - vitamin A, folic acid, zinc and selenium . . . . . . . . . . . . . . . . . . . . . . . . . . 590

4. Concluding remarks - the role of meat in human evolution and a healthy diet . . . . . . . . . . . . . . . . . . . . . . . . . . . . . 590

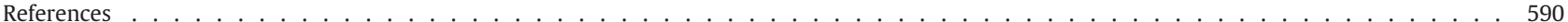

\section{Introduction}

Meat is a concentrated nutrient source, previously considered essential to optimal human growth and development (Higgs, 2000). Although some epidemiological data has revealed a possible association between its consumption and increased risk of several forms of cancer, cardiovascular and metabolic diseases, meat consumption has

\footnotetext{
* Corresponding author. Tel.: + 351212946700 ; fax: + 351212946768. E-mail addresses: pmccpereira@gmail.com (P.M.C.C. Pereira), filipavicente@hotmail.com (A.F.R.B. Vicente).

${ }^{1}$ Tel.: + 351 967787022; fax: + 351212946768 .
}

been important in human species evolution, especially the brain and intellectual development.

\section{The role of meat in human evolution}

Anthropology has previously recognized the importance of food and diet variations among time periods. It is possible to sum up the profile of meat consumption during human evolution in four periods: the first could be characterized by a opportunist hunting; while in the second, hunting had grown to a bigger scale and lasted 2 to 3 million years; in the third period, men started to domesticate animals and plants, which had began 10,000 years ago; during the fourth and 
last period studies determined that meat contained compounds which could increase disease risk (Larsen, 2003).

Eaton and Konner (1997) stated that human genes had not changed since the Paleolithic period. Human beings are animals, submitted to the same environmental pressure as other animals and living species (Zucoloto, 2011). With this scientists have proposed several possible influences of diet in human evolution in which some can be highlighted: cranial-dental and bowel morphologic changes and increased energy needs leading to an elevated quotient between brain and body size (Mann, 2007). Anthropological data have also suggested an important influence of meat consumption in human erect posture. Bipedalism is probably the first and most important characteristic which distinguished humans from their ancestors as it allowed a more efficient locomotion and load carrying, which are important advantages in hunting (Abitbol, 1995; Wang \& Crompton, 2004). Cranial-dental changes are quite visible when analyzing hominids fossils. Molar teeth size has decreased and the jaws and front teeth have become stronger. Also shearing crests have grown. These changes could be explained through the urgent need of tearing and chewing meat rather than grinding leaves, fruits, seeds and cereals (Speth, 1989).

Gastrointestinal tract features can also aid in determining dietary preferences considering that the gut of herbivores and pure carnivores suffered different physiological and metabolic adaptations. On one hand, plant-based diets are associated with a sacculated stomach and well-developed caecum and colon, which increased with plant fiber content. On the other hand, a carnivore's stomach is welldeveloped and acidic with a large small intestine. Humans are omnivorous thus fitting in neither category. They have a simple stomach and a relatively long small intestine but also a reduced caecum and colon (Mann, 2007).

The fact that the small intestine is the most prominent organ in the human gastrointestinal tract is due to the need for adaptation to a varied diet, including nutritionally dense foods, with great volume and conducive to being digested in the small intestine (Milton, 1999).

Considering their body size, primates in general and humans in particular, have metabolically expensive large brains which are due to the so called encephalisation process (Aiello, 1992). However, according to Henneberg (Henneberg, Sarafis, \& Mathers, 1998), the unusual human brain encephalisation is not clearly related with increases in the human brain but a relative decrease in human body size. This could be explained by taking into account the macro-evolutive enlargement suffered by the human brain in parallel with other mammals, their co-evolution with body size, the micro-evolutive decrease in human body size during considerable intellectual and cultural changes, and the virtual absence of an intra-specific correlation between brain size and human intelligence assessment methods.

Independently of what led to encephalisation, brain chemistry can be characterized by two determinants: firstly, the brain has a constant ionic and electrical information flux without which it would die. Second, this sophisticated communication network is conducted by transmembrane transfer systems which are primarily composed of lipids (60\%). Brain lipids are composed of phosphoglycerides and cholesterol. They are particularly rich in long chain fatty acids, mainly arachidonic (20:4n:6) and docosahexaenoic acids (22:6n:3), both from animal tissues (Crawford, 1970).

Humans have inherited a weak capacity to produce taurine from its precursors methionine and cysteine (Chesney et al., 1998) possibly due to low levels of cysteine sulfinic acid decarboxylase (Schuller-Levis \& Park, 2006) thus it must be supplied through diet. Taurine can be found mainly in shellfish like scallops, mussels and clams as well as in chicken and turkey dark meat. Despite the fact that taurine is not incorporated in proteins, this aminoacid has shown several important biological functions such as acting like an antioxidant and anti-inflammatory agent which can be related to cardiovascular disease prevention and is almost exclusively found in animal products (Wójcik et al., 2010).
Other important compounds required by humans, such as heme compounds or other porphyrin iron rich compounds are only present in meat and are preferably absorbed from meat instead of their ionic iron forms. Herbivores cannot absorb these heme complexes and depend only on ionic forms for absorption (Bothwell \& Charlton, 1982).

Humans are intermediate hosts for parasites that affect carnivores, such as tapeworms from Taeniidae family from Taenia saginata and Taenia solium that can be present in raw meat (Henneberg et al., 1998).

\section{Meat nutritional composition}

In European legislation, the term meat refers to the edible parts removed from the carcass of domestic ungulates including bovine, porcine, ovine and caprine animals as well as domestic solipeds; poultry; lagomorphs; wild game; farmed game; small and large wild game (European Comission, 2004).

Generally speaking, meat is an important source of several nutrients. It is particularly rich in high biological value protein, as well as micronutrients like iron, selenium, zinc and vitamin B12. Offal meats like liver are also crucial sources of vitamin A and folic acid (Biesalski, 2005).

\subsection{Meat protein content and protein value}

The role of meat, especially red meat, as a protein source is unequivocal. However, meat protein content can vary substantially. According to the Portuguese nutritional table data (INSRJ, 2006) the average protein content is $22 \%$, however it can be as high as $34.5 \%$ (chicken breast) or as low as $12.3 \%$ (duck meat).

It is also important to note that this protein has high digestibility scores as determined by the Protein Digestibility-Corrected Amino Acid Scores (PDCAAS). The higher PDCAAS 1.00 have been attributed to egg white and casein proteins. Meat scored 0.92 , while pinto beans, lentils, peas and chickpeas which are broadly considered important protein sources in vegetarian diets scored values from 0.57 to 0.71 and wheat gluten had been classified with a 0.25 score (FAO/WHO, 1991).

Additionally, meat proteins have been distinguished by their essential amino acids content. Amino acids are proteins' building blocks. There are one hundred and ninety amino acids known although only twenty are necessary to synthesize proteins ( Wu, 2009). Within this twenty, eight cannot be produced by the human body which makes them essential, thus they have to be supplied by diet. Both essential and non essential amino acids are presented in Table 1. Even if these non essential amino acids can be produced by the human body, it is mandatory to have all the raw materials necessary for their production. Inadequate consumption of amino acids, the primary units of proteins, can lead to protein malnutrition.

The nutritional value of each food can be determined by the quantity and the quality of the several amino acids present or absent. If a

Table 1

Essential amino acids and non-essential amino acids (Wu, 2009).

\begin{tabular}{ll}
\hline Essential amino acids & Non essential amino acids \\
\hline & Alanine \\
& Asparagine \\
Isoleucine & Arginine \\
Leucine & Cysteine \\
Lysine & Aspartic acid \\
Methionine & Glutamic acid \\
Tryptophan & Proline \\
Treonine & Hystidine \\
Valine & Tyrosin \\
Phenilalanine & Serin \\
& Glycine \\
\hline
\end{tabular}


certain food supplies enough of seven of the eight essential amino acids, the lacking amino acid is defined as the "limiting amino acid." In addition to its richness, meat protein distinguishes itself because of its richness in all the essential amino acids with no limiting amino acids (Williams, 2007). Vegetarians have to combine cereal and legumes to get all the essential amino acids. Cereals like rice and wheat are especially poor in lysine while legumes have low contents of methionine (Elango, Ball, \& Pencharz, 2009).

\subsection{Fat content}

Fat content differs significantly among retail beef cuts, poultry and other meat products such as offal and specialties like sausages, ham, etc. Table 2 sums up some of the main differences that can be observed among several cuts. Loin is the leanest portion in both beef and pork while breast is generally the leanest part in poultry meat.

Beef and pork are the most consumed meats in Portugal in spite of an increase in poultry products (INE, 2011). According to the Portuguese nutritional composition table (INSRJ, 2006), beef retail cuts range from $14 \%$ (calf) to $19 \%$ (adult animal), while pork can be 8 to $28 \%$ fat. Despite differences that could be expected within the same species of different origins, Williams reported similar results for fat content in beef (Williams, 2007). The USDA reports values from 5.4 to $7.9 \%$ fat in beef retail cuts (USDA, 2011). Pork fat ranges from 8 to $10.7 \%$ in the USDA tables, however this report considers mainly lean cuts (USDA, 2011).

Skin is probably the main source of fat in poultry meat, the fat content in the main retail cuts from chicken and turkey range from 1 to $15 \%$ but cuts including skin had higher values. Chicken and turkey breasts have similar fat contents while turkey legs tend to have higher fat contents than chicken legs (INSRJ, 2006).

Cooking can have a major influence in meat fat content and fatty acid composition. Gerber, Scheeder, and Wenk (2009) have shown considerable fat losses in several meat cuts submitted to grilling, broiling or pan-frying without fat added. Specifically regarding fatty acid composition, an increase in polyunsaturated/saturated ratio was observed, as also reported by Ono et al. (Ono, Berry, \& Paroczay, 1985) probably because polyunsaturated fatty acids are part of the cell membrane and thus have less contact with the heat.

\subsubsection{Fatty acid composition}

For several decades, dietary guidelines have recommended avoiding saturated fat in order to prevent cardiovascular disease (Krauss et al., 2000) leading to a significant decrease in the consumption of animal products especially meat. The mechanisms through which saturated fat exert pejorative effects in cardiovascular and general metabolic health are diverse, Kennedy, Martinez, Chuang, Lapoint, and Mcintosh (2009) have proposed that an excessive consumption of saturated fatty acids could promote white adipose tissue expansion and hypertrophy leading to apoptosis. These phenomena would promote the release of inflammatory proteins like cytokines and chemokines inducing inflammation and insulin resistance, thus increasing the risk of cardiovascular disease and metabolic syndrome (Haffner, 2006; Willerson \& Ridker, 2004).

Considering the important role of meat in the human diet and the estimated consumption growth through the years, and the concerns related to its role in human health, several studies have focused on ways of improving meat fatty acid composition, especially beef.

Ruminant intrinsic digestive characteristics affect meat fatty acid composition. Rumen microbial enzymes promote isomerisation and hydrolysis of unsaturated fatty acids leading to an increase in stearic acid concentration reaching the small intestine, the main absorption site. Ruminants have a high saturated fatty acid absorption efficiency attributed to a greater capacity of bile salts and the lysophospholipid micellar system to solubilise fatty acids and the low $\mathrm{pH}$ in the duodenum and jejunum ( $\mathrm{pH} 3.0-6.0$ ) which leads to a low concentration of hydrogen carbonate, reducing the conversion of saturated fatty acids into insoluble calcium salts which would not be absorbed by the enteroctyes (Woods \& Fearon, 2009). Considering this, despite a high concentration of linoleic (C18:2 n-6) and linolenic (C18:3n-3) in animal diet, the rumen process ensures that the major fatty acid leaving rumen is $\mathrm{C} 18: 0$ (stearic acid).

These features are especially advantageous considering the neutral role of stearic acid on cardiovascular disease risk (Hunter, Zhang, \& Kris-Etherton, 2010). It is also important to consider that humans can convert stearic acid to oleic acid, the main monounsaturated fatty acid in olive oil whose consumption has been associated with several health benefits (Covas, 2007; Perez-Jimenez et al., 2005).

It is also possible to find trans fatty acids in beef as they are formed as a result of the biohydrogenation by rumen bacteria. The most common and well known in meat from ruminant animals is conjugated linoleic acid (CLA), a trans fatty acid which has been linked to several health benefits like cardiovascular disease, diabetes and obesity prevention (Dilzer \& Park, 2012). However, the amount of CLA present in beef is minimal. Several studies report values of around $1 \mathrm{~g} / 100 \mathrm{~g}$ of fat from beef and 10 to $46 \mathrm{mg} / 100 \mathrm{~g}$ in trimmed fat meat (Droulez \& Levy, 2006).

Several studies had shown that meat fatty acid profile can be significantly influenced by feeding. Significant differences were found between pasture and grain-fed animal's fatty acid composition with higher polyunsaturated fatty acid concentrations in pasture fed groups. (Chilliard, Ferlay, \& Doreau, 2001; Dewhurst, Shingfield, Lee, \& Scollan, 2006; Lourenço, Van Ranst, Vlaeminck, De Smet, \& Fievez, 2008). Eriksson and Pickova (2007) suggested that fresh grass exerts a greater protection against rumen bacteria for polyunsaturated fatty acids than grains and it is also important to consider the presence of other secondary metabolites that could inhibit microbial biohydrogenation (Lourenço et al., 2008).

Within the polyunsaturated fatty acids, omega 3 fatty acids deserve special attention considering their recognized protective role

Table 2

Nutritional composition of several meat cuts (INSRJ, 2006).

\begin{tabular}{|c|c|c|c|c|c|c|c|c|c|}
\hline Meat cut & Energy value (kcal) & Protein $(\mathrm{g})$ & Fat $(\mathrm{g})$ & Saturated fat $(\mathrm{g})$ & Vitamin B12 (mcg) & $\mathrm{Na}(\mathrm{mg})$ & $\mathrm{P}(\mathrm{mg})$ & $\mathrm{Fe}(\mathrm{mg})$ & $\mathrm{Zn}(\mathrm{mg})$ \\
\hline Chicken breast, skinless, raw & 108 & 24.1 & 1.2 & 0.3 & 0.37 & 60 & 220 & 0.5 & 0.8 \\
\hline Chicken breast, raw & 176 & 24.1 & 8.9 & 2.1 & 0.37 & 72 & 200 & 1 & 0.8 \\
\hline Chicken, average, raw & 110 & 22.9 & 2 & 0.5 & 0.72 & 77 & 204 & 0.9 & 1 \\
\hline Beef, steak cuts, raw & 122 & 20.9 & 4.3 & 1.8 & 2 & 60 & 169 & 1.4 & 3.6 \\
\hline Beef, loin, raw & 114 & 21 & 3.3 & 1.4 & 2 & 60 & 145 & 1.5 & 3.6 \\
\hline Beef, calf, loin, raw & 148 & 19.9 & 7.6 & 3.2 & 1.2 & 24 & 195 & 0.9 & 3 \\
\hline Pork, loin, raw & 131 & 22.2 & 4.7 & 1.6 & 1 & 53 & 221 & 0.6 & 1.6 \\
\hline Pork, chop, raw & 355 & 17.3 & 31.8 & 10.9 & 1 & 61 & 189 & 1.3 & 1.7 \\
\hline Pork, leg, raw & 152 & 21 & 7.5 & $2 ., 6$ & 1 & 86 & 167 & 0.7 & 2.7 \\
\hline Turkey, breast, skinless, raw & 105 & 23.4 & 1.3 & 0.3 & 1 & 63 & 210 & 0.7 & 0.6 \\
\hline Turkey, average, skinless, raw & 137 & 20.5 & 6.1 & 2 & 2 & 49 & 210 & 2 & 1.6 \\
\hline Duck meat, average, skinless, raw & 133 & 19.3 & 6.2 & 1.6 & 3 & 92 & 202 & 2.4 & 1.9 \\
\hline Mutton, chop or meat, raw & 124 & 19.7 & 5 & 2.2 & 2 & 64 & 220 & 1.7 & 3.8 \\
\hline
\end{tabular}


in cardiovascular diseases and health promotion in general (Calder \& Yaqoob, 2009; Lavie, Milani, Mehra, \& Ventura, 2009). Seafood is the main source of omega 3. However meat can contribute up to $20 \%$ of long chain omega 3 polynsaturated fatty acid intake (Russo, 2009). Omega 3 content in meat depends mainly on the feeding system and it is higher in grass or forage-based diets (Nuernberg, Dannenberger, et al., 2005; Nuernberg, Fischer, et al., 2005; Realini, Duckett, Brito, Dalla Rizza, \& De Mattos, 2004). It can also be achieved through supplementation with fish oil (Wistuba, Kegley, \& Apple, 2006), linseed or flaxseed (Bilek \& Turhan, 2009; Kronberg, Barceló-Coblijn, Shin, Lee, \& Murphy, 2006). However, in some studies, undesirable flavor and palatibility changes have been reported especially with fish oil supplementation (Nuernberg, Dannenberger, et al., 2005; Nuernberg, Fischer, et al., 2005; Wistuba et al., 2006).

Due to their antithrombotic effects, the presence of omega 3 fatty acids in meat could counteract in part the pro thrombotic effect of omega 6 fatty acids. Meat is an important arachnidonic acid source, an omega 6 polynsaturated fatty acid which increases the risk of thrombosis (Christophersen \& Haug, 2011; Mann, Johnson, Warrick, \& Sinclair, 1995). Arachidonic acid is the precursor of thromboxane $\mathrm{A}_{2}$ which begins plaque aggregation, the primary phenomena in thrombosis development (Gabrielsen et al., 2010). Arterial thrombosis influences the evolution from a stable form of isquemic cardiac disease to an acute phase, shown by an unstable angina which can lead to myocardial disease and in sudden death (Libby, Ridker, \& Hansson, 2009).

Taking these data into account, it is relevant to consider controversies around meat consumption and disease risk. Some studies reviewed by (Micha, Wallace, \& Mozaffarian, 2010) have distinguished the influence of meat cuts from processed meat products in cardiovascular disease pointing out the need to consider processing techniques and cooking as important variables which could influence the final result and contribute to the bad image of meat.

\subsection{Vitamins and minerals}

Meat is an excellent source of several vitamins and minerals. Red meat provides around $25 \%$ of the recommended dietary intakes for riboflavin, niacin, vitamin $\mathrm{B} 6$ and pantothenic acid per $100 \mathrm{~g}$ and practically two thirds of the daily requirement (DR) of vitamin B12 in the same serving (Williams, 2007). In poultry, chicken breast is a particularly good source of niacin (100 g supplies $56 \%$ of DR) and vitamin B6 (27\% of DR) while $100 \mathrm{~g}$ of turkey breast supply $31 \%$ of niacin DR and $29 \%$ of vitamin B6 DR. Both supply between 6 to $8 \%$ of DR (USDA, 2011).

Meat is also one of the best sources for zinc, selenium phosphorus and iron. Beef lean cuts provide around 37\% of selenium DR, 26\% of zinc DR and $20 \%$ of potassium DR in a $100 \mathrm{~g}$ portion (USDA, 2011).

It is important to consider the influence of cooking techniques on vitamin and trace element contents considering that humans rarely eat raw meat. Some studies have shown that cooking in general produces significant losses of B vitamins (Lombardi-Boccia, Lanzi, \& Aguzzi, 2005). Several data suggest that B12 and thiamin are among the most affected B vitamins in compared with riboflavin and niacin which show lower decreases (D'Evoli et al., 2009; Riccio, Mennella, \& Fogliano, 2006). These losses could be due to two phenomena, on one hand B complex vitamins are water soluble thus some cooking methods may produce higher losses (boiling) and on the other hand, B vitamins are thermally instable thus shorter periods of cooking (stir frying) and underdone roasts may reduce these losses (Lombardi-Boccia et al., 2005; Yang \& Science, 1994).

\subsubsection{Meat, a valuable iron source}

Iron has a crucial role in human health and iron deficiency leads to an impairment of several biological functions as well as disturbances in child growth and development (Grantham-McGregor \& Ani, 2001;
Lozoff \& Georgieff, 2006). Its metabolism is distinct from other minerals considering that it is not excreted and $90 \%$ of its needs have an endogenous source, the breakdown of blood red cells. There are also obligatory losses through skin, intestines, urinary tract, airways and menstrual bleeding in women. The diet plays an essential role in maintaining iron balance (Hurrell \& Egli, 2010). Iron can be found in a broad variety of foods however it is present in two different forms: heme-iron and non-heme iron. Heme-iron comes from haemoglobin and myoglobin thus it is only present in animal foods. It is highly bioavailable and easily absorbed in the intestinal lumen because it is absorbed as an intact molecule by enterocytes (Hallberg \& Hulthén, 2000; Simpson \& McKie, 2009).

Non-heme iron which is present mainly in vegetables, with dark leaves like spinach and cruciferous vegetables, legumes and dairy products. The absorption of non-heme iron can be severely impaired and has a low bioavailability which ranges from 2 to 20\%(Turhan, Altunkaynak, \& Yazici, 2004). It is also important to note that vegetable iron sources are particularly rich in potential iron absorption inhibitors such as phytate (Kumar, Sinha, Makkar, \& Becker, 2010) and some phenolic compounds like polymerized flavans (Petry, Egli, \& Zeder, 2010) which can be found in legumes such as beans, faba beans are important iron sources in some populations (Luo, Xie, \& Cui, 2010; Petry et al., 2010). Sotello et al. (Sotelo, González-Osnaya, Sánchez-Chinchillas, \& Trejo, 2010) also suggested an inhibitory role of oxalate in iron absorption from vegetable sources such as spinach or kale, however these results are not in accordance with a study which evaluated directly iron absorption from these foods (Bonsmann, Walczyk, Renggli, \& Hurrell, 2008). Beans are also an important source of non-digestible carbohydrates which may impair iron absorption (Luo, Xie, \& Cui, 2010. However, controversies remain as some of these foods, such as cabbage (kale) are also good sources of ascorbic acid which improves iron absorption (Thumser, Rashed, Sharp, \& Lodge, 2010).

Neverthless heme-iron, even when consumed in smaller amounts, is two to three times more bioavailable and 15 to $35 \%$ is easily absorbed (Turhan et al., 2004). Meat is probably the best source of heme-iron. Previous studies have reported that 26.2 to $75.60 \%$ of its iron content is heme-iron. Beef has the highest content of heme-iron, loin can have 45\% (Kongkachuichai, Napatthalung, \& Charoensiri, 2002), to $77.58 \%$ (Lombardi-Boccia, Martinez-Dominguez, \& Aguzzi, 2002) while the average reported value was $58.10 \%$. Iron and heme-iron contents are lower in lighter meats such as chicken. Dark meat heme-iron is around $39.20 \%$ while light meat can have up to $26.15 \%$ (Clark, Mahoney, \& Carpenter, 1997). The average values for total iron and heme-iron are lower than those in beef.

Pork has intermediate values between beef and chicken. In loin cuts heme-iron can range from 38\% (Kongkachuichai et al., 2002) to $60 \%$ (Lombardi-Boccia et al., 2002) while tenderloin has only $23 \%$ (Hallberg \& Hulthén, 2000). Meat and meat products can contribute up to $18 \%$ of iron daily requirements (Geissler $\&$ Singh, 2011) which makes it important in a healthy balanced diet and crucial in preventing one of the most common nutritional deficiencies (WHO/ UNICEF/UNU, 2001).

However, despite its vital role in the human body, an excessive iron intake can be dangerous. High doses of iron can cause damage to intestinal mucosa and lead to systemic toxicity (Mills \& Curry, 1994). This excess can also induce free radical damage to several surrounding tissues (McCord, 1998). Recently, several studies have associated very high iron intakes with increased risk of colorectal cancer (Balder, Vogel, Jansen, \& Weijenberg, 2006), cardiovascular disease (Qi, van Dam, Rexrode, \& Hu, 2007), infection (Kontoghiorghes, Kolnagou, Skiada, \& Petrikkos, 2010), neurodegenerative diseases and inflammation (Thompson, Shoham, \& Connor, 2001).

For these reasons, there is a tolerable upper intake level which represents the highest intake that does not provoke adverse health effects. The value set in the USA was $45 \mathrm{mg} / \mathrm{day}$ for adults, mainly 
established based on secondary gastrointestinal distress symptoms (Geissler \& Singh, 2011).

\subsubsection{Vitamin $B 12$ in meat}

Meat is a valuable source of complex B vitamins, especially B12, the most complex and largest vitamin. Animal foods are considered the major dietary sources of vitamin B12, however, it can also be found in certain types of algae (Watanabe, 2007).

Vitamin B12 absorption is quite complex, cobalamin mixes with haptocorrin in the stomach, then after pancreatic protease actions it binds to intrinsic factor (IF), and is absorbed when it binds to specific receptors in the ileum mucosa. Then it is taken into lysosomes where cobalamin is released and metabolized to its methyl and deoxyadenosyl forms. When it reaches blood flow, it is transported and transferred to body cells bound to transcobalamin, which carries around $25 \%$ of plasmatic cobalamin (Allen, 2008). The absorption of IF-B12 significantly determines the dietary vitamin B12 bioavailability (Quadros, Nakayama, \& Sequeira, 2005).

Low dietary intake is probably the main cause of vitamin B12 deficiency. However it can also be due to absorptive process impairments provoked by gastric atrophy and malabsorption from food, quite frequent in elderly people (Allen, 2008). Strict vegetarianism is also associated with low vitamin B12 intake values (Craig, 2009; Millet, Guilland, Fuchs, \& Klepping, 1989). Vitamin B12 deficiency is the main cause of megaloblastic anemia. It is also strongly associated with high levels of blood homocysteine which is a cardiovascular disease risk factor (Green \& Miller, 2005). It can cause depressive symptoms as well as neurologic impairment (Agarwal, 2011).

However, there are some controversies around meat consumption and vitamin B12 status. Assumed bioavailability of dietary B12 is 50\%. More is not always better due to IF-mediated intestinal absorption saturation. Considering this vitamin B12 bioavailability can decrease with a high B12 ingestion in one only meal (Scott, 1997) which can justify some discrepancies in some results obtained on studies relating B12 intake and B12 blood levels (Vogiatzoglou et al., 2009).

Cosgrove, Flynn, and Kiely (2007) had studied the contribution of meat to daily intakes of several vitamins and minerals. According to their data, medium meat consumers, which represent 41-72 g/day in men and 24.2-45.5 g/day in females, consume in average $14.5 \pm$ $5 \mathrm{mg}$ and $20.2 \pm 28 \mathrm{mg}$ of iron, respectively for both sexes while in what concerns to vitamin B12 the average intake as $5.3 \pm 4 \mu \mathrm{g}$ in men and $6.5 \pm 6 \mu \mathrm{g}$ in women which satisfy the daily requirement for both micronutrients (Otten, Hellwig, \& Meyers, 2006).

\subsubsection{Other vitamins - vitamin A, folic acid, zinc and selenium}

Meat and meat products are also important sources of other micronutrients which are vital in human health.

Vitamin A is an essential vitamin for growth and development. Meat itself is not an important source of this micronutrient except if for offal meats. Liver is a good source of retinol considering that $100 \mathrm{~g}$ supply more than $338 \%$ of the dietary recommended value (USDA, 2011).

The same is true for folic acid which can be mainly found in beef liver. Together with B12, folic acid is an important methyl donor which is crucial for fetal development (Zeisel, 2009) and it seems to be important in DNA methylation, being associated with cancer prevention (Anderson, Sant, \& Dolinoy, 2012). Liver, especially from pigs, is a great source of folic acid supplying $81 \%$ of DR while calf liver supplies $87 \%$ of DR. Within vegetable sources, pinto beans and enriched wholegrain breakfast cereals are the best accomplishing $85 \%$ and $53 \%$ of DR (INSRJ, 2006; USDA, 2011).

Adequate zinc intake is essential for human health considering its functional roles in enzymatic systems, cell division and growth, gene expression, immune and reproductive functions. Zinc deficiencies increase the risk of infection, oxidative stress and genetic damage (Prasad, 2009). Finally, selenium is an essential trace element in
Table 3

Comparison of meat and vegetable based diets.

\begin{tabular}{ll}
\hline Advantages of Vegetarian diets & Advantages of meat consumption \\
\hline High fiber content & Energy and nutrient dense food \\
$\begin{array}{l}\text { Possibly lower energy content } \\
\text { Possibly higher antioxidant intake }\end{array}$ & $\begin{array}{l}\text { High biological value protein } \\
\text { Best source for iron, zinc and complex } \\
\text { Lower satureted fat intake }\end{array}$ \\
$\begin{array}{ll}\text { B vitamins especially B12 } \\
\text { Disadvantages of vegetarian diets }\end{array}$ & Disadvantages of meat consumption \\
\hline Lower iron bioavailability & High fat content in some cuts \\
Zinc and Vitamin B12 deficiency risk & Sodium content (processed meats) \\
Lack of EPA+DHA sources & Other contaminants (hormones) \\
Lower protein biological value & \\
\hline
\end{tabular}

human nutrition being the component of selenoproteins which have antioxidant functions in cardiovascular disease and cancer prevention (Rayman, 2000). $100 \mathrm{~g}$ of beef provides around 26\% of zinc DR. (USDA, 2011).

Selenium, though present in meat, may be found in higher values in seafood. Selenium has an important role in glutathione peroxidise activity, a crucial enzyme in detoxification processes. At higher levels, selenium itself can also exert an anti-carcinogenic effect as shown in several studies. The recommended dietary allowance of selenium is $55 \mu \mathrm{g} /$ day for adults (Food and Nutrition Board \& I. of M., 2000). Its content can range from 40 to $50 \mathrm{mcg} / 100 \mathrm{~g}$ of fresh meat. However, the bioavailability of selenium is quite variable though meat cuts have good bioavailability (Fairweather-tait, Collings, \& Hurst, 2010).

\section{Concluding remarks - the role of meat in human evolution and a healthy diet}

The growing incidence of several chronic diseases such as cancer and cardiovascular diseases has motivated extensive research into the foods associated with increased risk. Despite its nutritional richness, meat consumption has been considered a disease-promoting food.

Recently, research has started to demystify this negative health image and has helped to point out the crucial role of meat in human evolution, especially red meat.

Meat consumption has contributed to human gastrointestinal tract development, as well as crucial cranio-dental features and also posture, helping distinguish man from other hominids.

Meat continues to supply nutrients and plays a vital role in human life because of its high biological value protein, iron, zinc, selenium and vitamin B12 contents being a crucial component of a well balanced diet.

Fat content, a matter of concern regarding meat consumption, is highly variable depending on species, origin, feeding system and the cut. Leaner cuts like pork or beef loin do not differ significantly from skinless turkey or chicken breast and the nutritional richness justifies their inclusion in a well balanced diet.

Table 3 sums up the main advantages of a meat based diet compared to a vegetarian one. Removing this component from diet could increase the risk of severe nutritional deficiencies and impair human health and nutritional status.

\section{References}

Abitbol, M. (1995). Speculation on posture, locomotion, energy consumption, and blood flow in early hominids. Gait E' Posture, 3, 29-37.

Agarwal, R. (2011). Vitamin B12 deficiency \& cognitive impairment in elderly population. The Indian Journal of Medical Research, 134(4), 410-412. (Retrieved from http://www.ncbi.nlm.nih.gov/pmc/articles/PMC3237236/?report=printable)

Aiello, L. C. (1992). Allometry and the analysis of size and shape in human evolution. Journal of Human Evolution, 22(2), 127-147. http://dx.doi.org/10.1016/00472484(92)90034-7. 
Allen, L. H. (2008). Causes of vitamin B12 and folate deficiency. Food and Nutrition Bulletin, 29(2 Suppl.), S20-S34. (discussion S35-7. Retrieved from http://www. ncbi.nlm.nih.gov/pubmed/18709879)

Anderson, O. S., Sant, K. E., \& Dolinoy, D. C. (2012). Nutrition and epigenetics: an interplay of dietary methyl donors, one-carbon metabolism and DNA methylation. The Journal of Nutritional Biochemistry. http://dx.doi.org/10.1016/j.jnutbio.2012.03.003.

Balder, H. F., Vogel, J., Jansen, M. C. J. F., Weijenberg, M. P., van den Brandt, P. A Westenbrink, S., van der Meer, R., et al. (2006). Heme and chlorophyll intake and risk of colorectal cancer in the Netherlands cohort study. Cancer epidemiology, biomarkers \& prevention: a publication of the American Association for Cancer Research, cosponsored by the American Society of Preventive Oncology. Cancer Epidemiology Biomarkers \& Prevention, 15(4), 717-25. http://dx.doi.org/10.1158/ 1055-9965. EPI-05-0772.

Biesalski, H. -K. (2005). Meat as a component of a healthy diet - are there any risks or benefits if meat is avoided in the diet? Meat Science, 70(3), 509-524. http://dx.doi.org/ 10.1016/j.meatsci.2004.07.017.

Bilek, A., \& Turhan, S. (2009). Enhancement of the nutritional status of beef patties by adding flaxseed flour. Meat Science, 82(4), 472-477. http://dx.doi.org/ 10.1016/j.meatsci.2009.03.002

Bonsmann, S., Walczyk, T., Renggli, S., \& Hurrell, R. (2008). Oxalic acid does not influence nonhaem iron absorption in humans: a comparison of kale and spinach meals. European Journal of Clinical Nutrition, 62(3), 336-341. http://dx.doi.org/ 10.1038/sj.ejcn.1602721.

Bothwell, T. H., \& Charlton, R. W. (1982). A general approach to the problems of iron deficiency and iron overload in the population at large. Seminars in Hematology, 19(1), 54-67. (Retrieved from http://www.ncbi.nlm.nih.gov/pubmed/6763339)

Calder, P. C., \& Yaqoob, P. (2009). Omega-3 polyunsaturated fatty acids and human health outcomes. BioFactors (Oxford, England), 35(3), 266-272. http://dx.doi.org/ 10.1002/biof.42.

Chesney, R. W., Helms, R. A., Christensen, M., Budreau, A. M., Han, X., \& Sturman, J. A. (1998). The role of taurine in infant nutrition. Advances in Experimental Medicine and Biology, 442, 463-476. (Retrieved from http://www.ncbi.nlm.nih.gov/pubmed/ 9635063)

Chilliard, Y., Ferlay, A., \& Doreau, M. (2001). Effect of different types of forages, anima fat or marine oils in cow's diet on milk fat secretion and composition, especially conjugated linoleic acid ( CLA ) and polyunsaturated fatty acids. Livestock Production Science, $70,31-48$.

Christophersen, O. A., \& Haug, A. (2011). Animal products, diseases and drugs: a plea for better integration between agricultural sciences, human nutrition and huma pharmacology. Lipids in Health and Disease, 10(1), 16. http://dx.doi.org/10.1186/ 1476-511X-10-16.

Clark, E. M., Mahoney, A. W., \& Carpenter, C. E. (1997). Heme and total iron in ready-to-eat chicken $\dagger$. Journal of Agricultural and Food Chemistry, 45(1), 124-126. http://dx.doi.org/10.1021/jf960054l.

Cosgrove, M., Flynn, A., \& Kiely, M. (2007). Consumption of red meat, white meat and processed meat in Irish adults in relation to dietary quality. The British Journal of Nutrition, 93(06), 933. http://dx.doi.org/10.1079/BJN20051427.

Covas, M. -I. (2007). Olive oil and the cardiovascular system. Pharmacological research : the official journal of the Italian Pharmacological Society, 55(3), 175-186. http://dx.doi.org/ 10.1016/j.phrs.2007.01.010.

Craig, W. J. (2009). Health effects of vegan diets. The American Journal of Clinical Nutrition, 89(5), 1627S-1633S. http://dx.doi.org/10.3945/ajcn.2009.26736N.

Crawford, M. A. (1970). Studies on fa ' $m$ ' y acid composition meats of wild and domestic Methods, 295-305.

D'Evoli, L., Salvatore, P., Lucarini, M., Nicoli, S., Aguzzi, A., Gabrielli, P., et al. (2009). Nutritional value of traditional Italian meat-based dishes: influence of cooking methods and recipe formulation. International Journal of Food Sciences and Nutrition, 60(Suppl. 5), 38-49. http://dx.doi.org/10.1080/09637480802322103.

Dewhurst, R. J., Shingfield, K. J., Lee, M. R. F., \& Scollan, N. D. (2006). Increasing the concentrations of beneficial polyunsaturated fatty acids in milk produced by dairy cows in high-forage systems. Animal Feed Science and Technology, 131(3-4), 168-206. http://dx.doi.org/10.1016/j.anifeedsci.2006.04.016.

Dilzer, A., \& Park, Y. (2012). Implication of conjugated linoleic acid (CLA) in human health. Critical Reviews in Food Science and Nutrition, 52(6), 488-513. http://dx.doi.org/ $10.1080 / 10408398.2010 .501409$.

Droulez, V., \& Levy, G. (2006). Composition of Australian red meat 2002. 2. Fatty acid profile. Word Journal of The International Linguistic Association, 58(7), 335-341.

Eaton, S. B., \& Konner, M. J. (1997). Review paleolithic nutrition revisited: a twelve-year retrospective on its nature and implications. European Journal of Clinical Nutrition, 51(4), 207-216. http://dx.doi.org/10.1038/sj.ejen.1600389.

Elango, R., Ball, R. O., \& Pencharz, P. B. (2009). Amino acid requirements in humans: With a special emphasis on the metabolic availability of amino acids. Amino Acids, 37(1), 19-27. http://dx.doi.org/10.1007/s00726-009-0234-y.

Eriksson, S., \& Pickova, J. (2007). Fatty acids and tocopherol levels in M. Longissimus dorsi of beef cattle in Sweden - A comparison between seasonal diets. Meat Science, 76(4), 746-754. http://dx.doi.org/10.1016/j.meatsci.2007.02.021.

European Comission REG (EC) No835/2004. 2002 Regulation (2004). EUOJ L139/55.

Fairweather-tait, S. J., Collings, R., \& Hurst, R. (2010). Selenium bioavailability: current knowledge and future research. American Journal of Clinical Nutrition, 91(2). http://dx. doi.org/10.3945/ajcn.2010.28674J.The.

FAO/WHO (1991). Protein quality evaluation.pdf. (Rome, Italy. Retrieved from http:// www.fao.org/docrep/013/t0501e/t0501e00.pdf)

Food and Nutrition Board, I. of M. (2000). Dietary Reference Intakes for Vitamin C, Vita$\min$ E, Selenium, and Carotenoids. Washington, D.C.: The National Academies Press.

Gabrielsen, A., Qiu, H., Bäck, M., Hamberg, M., Hemdahl, A. -L., Agardh, H., et al. (2010) Thromboxane synthase expression and thromboxane A2 production in the atherosclerotic lesion. Journal of molecular medicine (Berlin, Germany), 88(8), 795-806. http://dx.doi.org/10.1007/s00109-010-0621-6.

Geissler, C., \& Singh, M. (2011). Iron, meat and health. Nutrients, 3(3), 283-316. http://dx.doi.org/10.3390/nu3030283.

Gerber, N., Scheeder, M. R. L., \& Wenk, C. (2009). The influence of cooking and fat trimming on the actual nutrient intake from meat. Meat Science, 81(1), 148-154. http://dx.doi.org/ 10.1016/j.meatsci.2008.07.012.

Grantham-McGregor, S., \& Ani, C. (2001). A review of studies on the effect of iron deficiency on cognitive development in children. The Journal of Nutrition, 131(2), 649S-668S. (Retrieved from http://jn.nutrition.org/cgi/content/abstract/131/2/649S)

Green, R. \& Miller J. W. (2005). Vitamin B12 deficiency is the dominant nutritional cause of hyperhomocysteinemia in a folic acid-fortified population. Clinical chemistry and laboratory medicine: CCLM/FESCC, 43(10), 1048-1051. http://dx.doi.org/10.1515/ CCLM.2005.183.

Haffner, S. M. (2006). The metabolic syndrome: inflammation, diabetes mellitus, and cardiovascular disease. The American Journal of Cardiology, 97(2A), 3A-11A. http://dx.doi.org/10.1016/j.amjcard.2005.11.010.

Hallberg, L., \& Hulthén, L. (2000). Prediction of dietary iron absorption: an algorithm for calculating absorption and bioavailability of dietary iron. The American Journal of Clinical Nutrition, 71(5), 1147-1160. (Retrieved from http://www.ncbi.nlm.nih. gov/pubmed/10799377)

Henneberg, M., Sarafis, V., \& Mathers, K. (1998). Human adaptations to meat eating. Human Evolution, 13(3-4), 229-234. http://dx.doi.org/10.1007/BF02436507.

Higgs, J. D. (2000). The changing nature of red meat: 20 years of improving nutritional quality. Trends in Food Science \& Technology, 11(3), 85-95. http://dx.doi.org/ 10.1016/S0924-2244(00)00055-8.

Hunter, J. E., Zhang, J., \& Kris-Etherton, P. M. (2010). Cardiovascular disease risk of dietary stearic acid compared with trans, other saturated, and unsaturated fatty acids: a systematic review. The American Journal of Clinical Nutrition, 91(1), 46-63. http://dx.doi.org/10.3945/ajcn.2009.27661

Hurrell, R., \& Egli, I. (2010). Iron bioavailability and dietary reference values $1-4$. The American Journal of Clinical Nutrition, 91, 1461S-1467S. http://dx.doi.org/10.3945/ ajcn.2010.28674F.1.

INE. (2011). Censos. Lisboa.

INSRJ (2006). Tabela de Composição de Alimentos. Lisbon.

Kennedy, A., Martinez, K. Chuang, C., Lapoint, K., \& Mcintosh, M. (2009). Saturated fatty acid-mediated inflammation and insulin resistance in adipose tissue. Mechanisms of Action and Implications, 1, 1-4. http://dx.doi.org/10.3945/jn.108.098269.1.

Kongkachuichai, R., Napatthalung, P., \& Charoensiri, R. (2002). Heme and nonheme iron content of animal products commonly consumed in thailand. Journal of Food Composition and Analysis, 15(4), 389-398. http://dx.doi.org/10.1006/jfca.2002.1080.

Kontoghiorghes, G. J., Kolnagou, A., Skiada, A., \& Petrikkos, G. (2010). The role of iron and chelators on infections in iron overload and non iron loaded conditions: prospects for the design of new antimicrobial therapies. Hemoglobin, 34(3), 227-239. http://dx.doi.org/10.3109/03630269.2010.483662.

Krauss, R. M., Eckel, R. H., Howard, B., Appel, L. J., Daniels, S. R., Deckelbaum, R. J., et al. (2000). AHA dietary guidelines: Revision 2000: A statement for healthcare professionals from the Nutrition Committee of the American Heart Association. Circulation, 102(18), 2284-2299. http://dx.doi.org/10.1161/01.CIR.102.18.2284.

Kronberg, S. L., Barceló-Coblijn, G., Shin, J., Lee, K., \& Murphy, E. J. (2006). Bovine muscle n-3 fatty acid content is increased with flaxseed feeding. Lipids, 41(11), 1059-1068. (Retrieved from http://www.ncbi.nlm.nih.gov/pubmed/17263305)

Kumar, V., Sinha, A. K., Makkar, H. P. S., \& Becker, K. (2010). Dietary roles of phytate and phytase in human nutrition: A review. Food Chemistry, 120(4), 945-959. http://dx.doi.org/10.1016/j.foodchem.2009.11.052.

Larsen, C. S. (2003). Animal source foods to improve micronutrient nutrition and human function in developing countries animal source foods and human health during evolution. Health (San Francisco), 1(2), 3893-3897.

Lavie, C. J., Milani, R. V., Mehra, M. R., \& Ventura, H. O. (2009). Omega-3 polyunsaturated fatty acids and cardiovascular diseases. Journal of the American College of Cardiology, 54(7), 585-594. http://dx.doi.org/10.1016/j.jacc.2009.02.084.

Libby, P., Ridker, P. M., \& Hansson, G. K. (2009). Inflammation in atherosclerosis: From pathophysiology to practice. Journal of the American College of Cardiology, 54(23), 2129-2138. http://dx.doi.org/10.1016/j.jacc.2009.09.009.

Lombardi-Boccia, Ginevra, Lanzi, S., \& Aguzzi, A. (2005). Aspects of meat quality: Trace elements and B vitamins in raw and cooked meats. Journal of Food Composition and Analysis, 18(1), 39-46. http://dx.doi.org/10.1016/j.jfca.2003.10.007.

Lombardi-Boccia, G., Martinez-Dominguez, B., \& Aguzzi, A. (2002). Total heme and non-heme iron in raw and cooked meats. Journal of Food Science, 67(5), 1738-1741. http://dx.doi.org/10.1111/j.1365-2621.2002.tb08715.x.

Lourenço, M., Van Ranst, G., Vlaeminck, B., De Smet, S., \& Fievez, V. (2008). Influence of different dietary forages on the fatty acid composition of rumen digesta as well as ruminant meat and milk. Animal Feed Science and Technology, 145(1-4), 418-437. http://dx.doi.org/10.1016/j.anifeedsci.2007.05.043.

Lozoff, B., \& Georgieff, M. K. (2006). Iron deficiency and brain development. Seminars in Pediatric Neurology, 13(3), 158-165. http://dx.doi.org/10.1016/j.spen.2006.08.004.

Luo, Y., Xie, W., Cui, Q. (2010). Journal of Food Science 75(2): C191-C198. http://10. $1111 / \mathrm{j} .1750-3841.2009 .01490 . x$

Mann, Neil (2007). Meat in the human diet: An anthropological perspective. Nutrition and Dietetics, 64(s4), S102-S107. http://dx.doi.org/10.1111/j.1747-0080.2007.00194x (The Role of).

Mann, N., Johnson, L., Warrick, G., \& Sinclair, A. (1995). The arachidonic acid content of the australian diet is lower than previously estimated. The Journal of Nutrition, 12, $2528-2535$.

McCord, J. M. (1998). Iron, free radicals, and oxidative injury. Seminars in Hematology, 35(1), 5-12. (Retrieved from http://www.ncbi.nlm.nih.gov/pubmed/9460805) 
Micha, R., Wallace, S. K., \& Mozaffarian, D. (2010). Red and processed meat consumption and risk of incident coronary heart disease, stroke, and diabetes mellitus: A systematic review and meta-analysis. Circulation, 121(21), 2271-2283. http://dx.doi.org/ 10.1161/CIRCULATIONAHA.109.924977.

Millet, P., Guilland, J., Fuchs, F., \& Klepping, J. (1989). Nutrient intake and vitamin status of healthy French vegetarians and nonvegetarians. The American Journal of Clinical Nutrition, 50(4), 718-727. (Retrieved from http://www.ajcn.org/cgi/content/ abstract/50/4/718)

Mills, K. C., \& Curry, S. C. (1994). Acute iron poisoning. Emergency Medicine Clinics of North America, 12(2), 397-413. (Retrieved from http://www.ncbi.nlm.nih.gov/ pubmed/8187690)

Milton, K. (1999). A hypothesis to explain the role of meat-eating in human evolution Evolutionary Anthropology: Issues, News, and Reviews, 8(1), 11-21. http://dx.doi.org/ 10.1002/(SICI)1520-6505(1999) 8:1<11::AID-EVAN6>3.3.CO;2-D

Nuernberg, K., Dannenberger, D., Nuernberg, G., Ender, K., Voigt, J., Scollan, N. D., et al (2005). Effect of a grass-based and a concentrate feeding system on meat quality characteristics and fatty acid composition of longissimus muscle in different cattle breeds. Livestock Production Science, 94(1-2), 137-147. http://dx.doi.org/10.1016/ j.livprodsci.2004.11.036.

Nuernberg, K., Fischer, K., Nuernberg, G., Kuechenmeister, U., Klosowska, D. Eliminowska-Wenda, G., et al. (2005). Effects of dietary olive and linseed oil on lipid composition, meat quality, sensory characteristics and muscle structure in pigs. Meat Science, 70(1), 63-74. http://dx.doi.org/10.1016/j.meatsci.2004.12.001.

Ono, K., Berry, B. W., \& Paroczay, E. (1985). Journal of Food Science, 50(3), 701-706.

Otten, J., Hellwig, J., \& Meyers, L. (2006). Dietary reference intakes: The essential guide to nutrient requirements. Washington, D.C.: The National Academies Press.

Perez-Jimenez, F., Alvarez de Cienfuegos, G., Badimon, L., Barja, G., Battino, M., Blanco, A., et al. (2005). International conference on the healthy effect of virgin olive oil. European Journal of Clinical Investigation, 35(7), 421-424. http://dx.doi.org/10.1111/ j.1365-2362.2005.01516.x

Petry, N., Egli, I., \& Zeder, C. (2010). Polyphenols and phytic acid contribute to the low iron bioavailability from common beans in young women. The Journal of Nutrition, 140, 1977-1982. http://dx.doi.org/10.3945/jn.110.125369.phenolic.

Prasad, A. S. (2009). Impact of the discovery of human zinc deficiency on health. Journal of the American College of Nutrition, 28(3), 257-265. (Retrieved from http://www. ncbi.nlm.nih.gov/pubmed/20150599)

Qi, L., van Dam, R. M., Rexrode, K., \& Hu, F. B. (2007). Heme iron from diet as a risk factor for coronary heart disease in women with type 2 diabetes. Diabetes Care, 30(1), 101-106. http://dx.doi.org/10.2337/dc06-1686.

Quadros, E. V., Nakayama, Y., \& Sequeira, J. M. (2005). The binding properties of the human receptor for the cellular uptake of vitamin B12. Biochemical and Biophysical Research Communications, 327(4), 1006-1010. http://dx.doi.org/10.1016/j.bbrc.2004.12.103.

Rayman, M. P. (2000). The importance of selenium to human health. The Lancet 356(9225), 233-241. http://dx.doi.org/10.1016/S0140-6736(00)02490-9.

Realini, C. E., Duckett, S. K., Brito, G. W., Dalla Rizza, M., \& De Mattos, D. (2004). Effect of pasture vs. concentrate feeding with or without antioxidants on carcass characteristics, fatty acid composition, and quality of Uruguayan beef. Meat Science, 66(3), 567-577. http://dx.doi.org/10.1016/S0309-1740(03)00160-8.

Riccio, F., Mennella, C., \& Fogliano, V. (2006). Effect of cooking on the concentration of Vitamins B in fortified meat products. Journal of Pharmaceutical and Biomedical Analysis, 41(5), 1592-1595. http://dx.doi.org/10.1016/j.jpba.2006.01.061.

Russo, G. L. (2009). Dietary n-6 and n-3 polyunsaturated fatty acids: From biochemistry to clinical implications in cardiovascular prevention. Biochemical Pharmacology, 77(6), 937-946. http://dx.doi.org/10.1016/j.bcp. 2008.10.020.

Schuller-Levis, G., \& Park, E. (2006). Advances in clinical chemistry volume 41, Vol. 41 Elsevier. http://dx.doi.org/10.1016/S0065-2423(05)41001-X.

Scott, J. M. (1997). Bioavailability of vitamin B12. European Journal of Clinical Nutrition, 51(Suppl. 1), S49-S53. (Retrieved from http://www.ncbi.nlm.nih.gov/pubmed/ 9023481)
Simpson, R. J., \& McKie, A. T. (2009). Regulation of intestinal iron absorption: The mucosa takes control? Cell Metabolism, 10(2), 84-87. http://dx.doi.org/10.1016/ j.cmet.2009.06.009.

Sotelo, A., González-Osnaya, L., Sánchez-Chinchillas, A., \& Trejo, A. (2010). Role of oxate, phytate, tannins and cooking on iron bioavailability from foods commonly consumed in Mexico. International Journal of Food Sciences and Nutrition, 61(1), 29-39. http://dx.doi.org/10.3109/09637480903213649.

Speth, J. D. (1989). Early hominid hunting and scavenging: The role of meat as an energy source. Journal of Human Evolution, 18(4), 329-343. http://dx.doi.org/10.1016/ 0047-2484(89)90035-3.

Thompson, K. J., Shoham, S., \& Connor, J. R. (2001). Iron and neurodegenerative disorders. Brain Research Bulletin, 55(2), 155-164. http://dx.doi.org/10.1016/ S0361-9230(01)00510-X.

Thumser, A. E., Rashed, A. A., Sharp, P. A., \& Lodge, J. K. (2010). Ascorbate enhances iron uptake into intestinal cells through formation of a $\mathrm{FeCl} 3$-ascorbate complex. Food Chemistry, 123(2), 281-285. http://dx.doi.org/10.1016/j.foodchem.2010.04.031.

Turhan, S., Altunkaynak, T. B., \& Yazici, F. (2004). A note on the total and heme iron contents of ready-to-eat doner kebabs. Meat Science, 67(2), 191-194. http://dx.doi.org/ 10.1016/j.meatsci.2003.10.004.

USDA (2011). USDA National Nutrient Database for Standard Reference, Release 24. (Retrieved from http://www.ars.usda.gov/nutrientdata)

Vogiatzoglou, A., Oulhaj, A., Smith, A. D., Nurk, E., Drevon, C. A., Ueland, P. M., et al. (2009). Determinants of plasma methylmalonic acid in a large population: implications for assessment of vitamin B12 status. Clinical Chemistry, 55(12), 2198-2206. http://dx.doi.org/10.1373/clinchem.2009.128678.

Wang, W. -J., \& Crompton, R. H. (2004). The role of load-carrying in the evolution of modern body proportions. Journal of Anatomy, 204(5), 417-430. http://dx.doi.org/10.1111/ j.0021-8782.2004.00295.x.

Watanabe, F. (2007). Vitamin B12 sources and bioavailability. Experimental Biology and Medicine (Maywood, N.J.), 232(10), 1266-1274. http://dx.doi.org/10.3181/ 0703-MR-67.

WHO/UNICEF/UNU (2001). Iron deficiency anaemia: Assessment, prevention and control. World Health Organisation.

Willerson, J. T., \& Ridker, P. M. (2004). Inflammation as a cardiovascular risk factor. Circulation, 109(21 Suppl. 1), II2-II10. http://dx.doi.org/10.1161/01.CIR.0000129535.04194.38.

Williams, P. (2007). Nutritional composition of red meat. s4 The Role of. Nutrition and Dietetics, 64, S113-S119. http://dx.doi.org/10.1111/j.1747-0080.2007.00197.x.

Wistuba, T. J., Kegley, E. B., \& Apple, J. K. (2006). Influence of fish oil in finishing diets on growth performance, carcass characteristics, and sensory evaluation of cattle The online version of this article, along with updated information and services, is located on the World Wide Web at : Influence. Journal of Animal Science, 84, 902-909.

Wójcik, O. P., Koenig, K. L., Zeleniuch-Jacquotte, A., Costa, M., \& Chen, Y. (2010). The potential protective effects of taurine on coronary heart disease. Atherosclerosis, 208(1), 19-25. http://dx.doi.org/10.1016/j.atherosclerosis.2009.06.002.

Woods, V. B., \& Fearon, A. M. (2009). Dietary sources of unsaturated fatty acids for animals and their transfer into meat, milk and eggs: A review. Livestock Science, 126(1-3), 1-20. http://dx.doi.org/10.1016/j.livsci.2009.07.002.

Wu, G. (2009). Amino acids: Metabolism, functions, and nutrition. Amino Acids, 37(1), 1-17. http://dx.doi.org/10.1007/s00726-009-0269-0.

Yang, J., \& Science, N. (1994). Sensory qualities and nutrient retention of beef strips prepared by different household cooking techniques. Journal of the American Dietetic Association, 94(2), 2-5.

Zeisel, S. H. (2009). Importance of methyl donors during reproduction 1 - 4. American Journal of Clinical Nutrition, 89(1), 673-677. http://dx.doi.org/10.3945/ajcn.2008. 26811D.FOLATE.

Zucoloto, F. (2011). Evolution of the human feeding behavior. Psychology \& Neuroscience, 4(1), 131-141. http://dx.doi.org/10.3922/j.psns.2011.1.015. 